\title{
Aquimarina mytili sp. nov., isolated from the gut microflora of a mussel, Mytilus coruscus, and emended description of Aquimarina macrocephali
}

\begin{abstract}
Correspondence
Chi Nam Seong

scnu@scnu.ac.kr
\end{abstract}

\section{Seong Chan Park, Han Na Choe, Keun Sik Baik and Chi Nam Seong}

\author{
Department of Biology, College of Life Science and Natural Resources, Sunchon National \\ University, Suncheon 540-742, Republic of Korea
}

The genus Aquimarina belongs to the family Flavobacteriaceae (phylum 'Bacteroidetes') and, at the time of writing, comprised seven recognized species: Aquimarina muelleri (type species), A. latercula, A. brevivitae, A. intermedia (Nedashkovskaya et al., 2005, 2006), A. macrocephali (Miyazaki et al., 2010), A. spongiae (Yoon et al., 2011) and A. addita (Yi \& Chun, 2011), all isolated from marine environments such as a marine aquarium, marine invertebrates, marine sediment and seawater. Aquimarina species are Gram-reaction-negative, strictly aerobic, chemo-organotrophic and pigmented bacteria. Here, we report the description of an Aquimarina-like strain, and show that this represents a novel species of the genus.

Strain PSC $33^{\mathrm{T}}$ was isolated from a sample of gut content obtained from a mussel (Mytilus coruscus) collected from Gwangyang Bay in the South Sea (34 53' N $\left.127^{\circ} 46^{\prime} \mathrm{E}\right)$, Republic of Korea, in February 2009. Isolation was achieved by using the standard dilution plating technique on marine agar (MA; Becton Dickinson) (Yang et al., 2006) incubated at $25{ }^{\circ} \mathrm{C}$ for 2 weeks. The isolate was routinely cultured on MA and preserved at $-80{ }^{\circ} \mathrm{C}$ as a suspension in marine broth (MB; Becton Dickinson) containing glycerol $(20 \%, \mathrm{w} / \mathrm{v})$. The following were used as reference

The GenBank/EMBL/DDBJ accession number for the 16S rRNA gene sequence of strain PSC33 ${ }^{\top}$ is HM998910.

Two supplementary figures are available with the online version of this paper. strains for all phenotypic tests: A. brevivitae KCTC $12390^{\mathrm{T}}$, A. intermedia JCM $13506^{\mathrm{T}}$, A. latercula JCM $8515^{\mathrm{T}}, A$. macrocephali $\mathrm{JCM} 15542^{\mathrm{T}}$, A. muelleri KCTC $12285^{\mathrm{T}}$ and A. spongiae $\mathrm{A6}^{\mathrm{T}}$.

Bacterial DNA preparation, and PCR amplification and sequencing of the $16 \mathrm{~S}$ rRNA gene were carried out as described by Chun \& Goodfellow (1995). Identification of phylogenetic neighbours and calculation of pairwise $16 \mathrm{~S}$ rRNA gene sequence similarities were achieved by using the EzTaxon server (http://www.eztaxon.org/; Chun et al., 2007). Related sequences and the novel sequence were aligned by using CLUSTAL X (Thompson et al., 1997), and the alignment was refined by using PHYDIT version 3.1 (http://plaza.snu.ac.kr/ jchun/phydit/). Phylogenetic analysis was performed by using the computer packages PHYLIP (Felsenstein, 1993) and PAUP ${ }^{\star} 4.0$ (Swofford, 1998). Phylogenetic trees were inferred with the neighbourjoining (Saitou \& Nei, 1987), Fitch-Margoliash (Fitch \& Margoliash, 1967), maximum-likelihood (Felsenstein, 1993) and maximum-parsimony (Fitch, 1971) algorithms. A distance matrix of the neighbour-joining dataset was generated according to the model of Jukes \& Cantor (1969). The robustness of the topology in the neighbourjoining phylogenetic tree was evaluated by bootstrap analyses (Felsenstein, 1985) based on 1000 resamplings.

Preliminary comparisons with 16S rRNA gene sequences held in GenBank indicated that the novel isolate was closely related to members of the genus Aquimarina. The newly 
determined sequence (1429 nt) was then aligned manually against representatives of the genus Aquimarina. Strain $\mathrm{PSC}_{3}{ }^{\mathrm{T}}$ showed highest $16 \mathrm{~S}$ rRNA gene sequence similarity to A. macrocephali JAMB $\mathrm{N} 27^{\mathrm{T}}(96.3 \%)$ and the type strains of other members of the genus Aquimarina (94.4$95.8 \%$ ). The neighbour-joining tree (Fig. 1) showed that strain $\mathrm{PSC} 33^{\mathrm{T}}$ was grouped with members of the genus Aquimarina and formed a distinct phyletic line. The topology of the other phylogenetic trees was essentially the same (data not shown). On the basis of 16S rRNA gene sequence similarity data and phylogenetic inference, it is clear that the isolate represents a novel genomic species within the genus Aquimarina (Wayne et al., 1987).

As levels of 16S rRNA gene sequence similarity between strain PSC $33^{\mathrm{T}}$ and the type strains of recognized Aquimarina species were below the level indicative of relatedness at the species level (97\%; Tindall et al., 2010), no DNA-DNA hybridization experiments were needed to define novel species status.

Growth was tested on nutrient agar (NA; Becton Dickinson), trypticase soy agar (TSA; Becton Dickinson), R2A agar (Becton Dickinson) and glucose-yeast extract agar (GYEA, containing per litre distilled water: $10 \mathrm{~g}$ yeast extract, $10 \mathrm{~g}$ glucose and $15 \mathrm{~g}$ agar). Cell morphology was observed by phase-contrast microscopy (TMS-F; Nikon) and scanning electron microscopy (S-4800; Hitachi) of cells of exponentially growing cultures. Gliding motility was examined by observing cells grown in wet mounts by using phase-contrast microscopy (DS-Fil; Nikon). Cells of strain PSC $33^{\mathrm{T}}$ and the six reference strains grown on $\mathrm{MA}$ at $25{ }^{\circ} \mathrm{C}$ for 3 days were used for physiological and biochemical tests. Growth was assessed in $\mathrm{MB}$ at $4,10-50$ (at $5{ }^{\circ} \mathrm{C}$ intervals), 37 and $42{ }^{\circ} \mathrm{C}$. Growth was assessed in $\mathrm{MB}$ adjusted to $\mathrm{pH} 4.0-10.0$ (at $1 \mathrm{pH}$ unit intervals) by using $100 \mathrm{mM}$ acetate buffer ( $\mathrm{pH} 4-5$ ), $100 \mathrm{mM} \mathrm{NaH}_{2} \mathrm{PO}_{4} / \mathrm{Na}_{2} \mathrm{HPO}_{4}$ buffer (pH 6-8) and $100 \mathrm{mM}$ $\mathrm{NaHCO}_{3} / \mathrm{Na}_{2} \mathrm{CO}_{3}$ buffer (pH 9-10) (Yumoto et al., 2004). The requirement for and tolerance to $\mathrm{NaCl}$ were determined in $\mathrm{NaCl}$-free artificial seawater medium (ASW, containing per litre distilled water: $5.9 \mathrm{~g} \mathrm{MgCl}_{2} .6 \mathrm{H}_{2} \mathrm{O}, 3.24 \mathrm{~g}$ $\mathrm{MgSO}_{4} .7 \mathrm{H}_{2} \mathrm{O}, 1.8 \mathrm{~g} \mathrm{CaCl} 2.2 \mathrm{H}_{2} \mathrm{O}, 0.55 \mathrm{~g} \mathrm{KCl}, 0.16 \mathrm{~g}$ $\mathrm{NaHCO}_{3}, \quad 0.08 \mathrm{~g} \quad \mathrm{KBr}, \quad 0.034 \mathrm{~g} \quad \mathrm{SrCl}_{2} .6 \mathrm{H}_{2} \mathrm{O}, \quad 0.022 \mathrm{~g}$ $\mathrm{H}_{3} \mathrm{BO}_{3}, 0.008 \mathrm{~g} \mathrm{Na}_{2} \mathrm{H}_{2} \mathrm{PO}_{4}, 0.004 \mathrm{~g} \mathrm{Na}_{2} \mathrm{SiO}_{3}, 0.0024 \mathrm{~g} \mathrm{NaF}$ and $0.0016 \mathrm{~g} \mathrm{NH}_{4} \mathrm{NO}_{3}$ ) supplemented with $5.0 \mathrm{~g}$ peptone, $1.0 \mathrm{~g}$ yeast extract and various concentrations of $\mathrm{NaCl}$ (Sigma) (final concentration 0-10\%, using increments of $1 \%)$ (Yang \& Cho, 2008). Anaerobic growth was tested on MA in a jar containing an AnaeroPak (Mitsubishi Gas

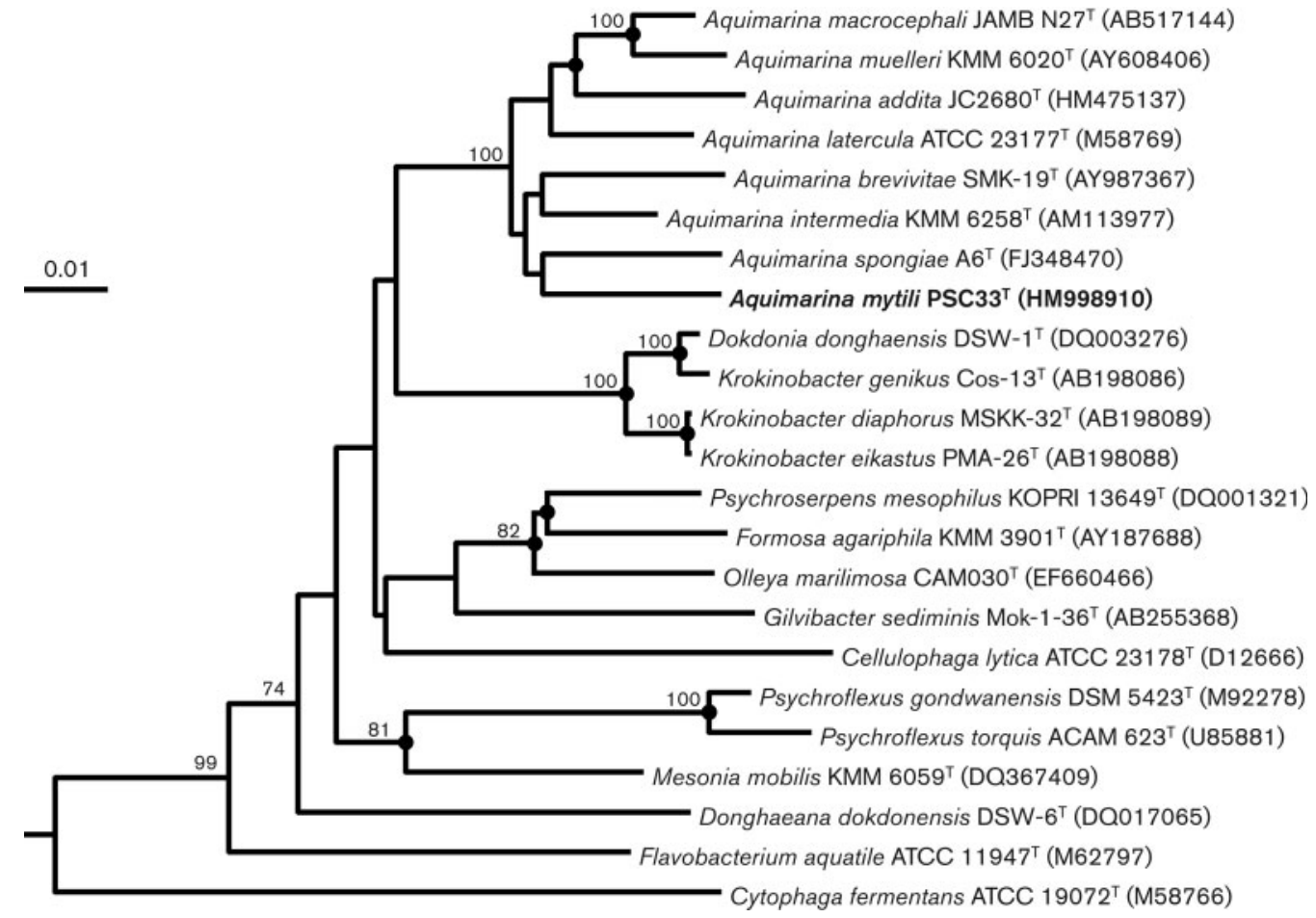

Fig. 1. Neighbour-joining tree based on $16 \mathrm{~S}$ rRNA gene sequences showing the phylogenetic position of strain $\mathrm{PSC}^{\mathrm{N}} 3^{\top}$, the type strains of recognized Aquimarina species and representatives of other genera in the family Flavobacteriaceae. Evolutionary distances, generated using the model of Jukes \& Cantor (1969), are based on 1112 unambiguously aligned nucleotides. Numbers at nodes are bootstrap values (percentages of 1000 resamplings); only values $\geqslant 70 \%$ are shown. Helicobacter pylori ATCC $43504^{\top}$ (U01330) was used as an outgroup (not shown). Filled circles indicate that the corresponding nodes were also recovered in trees generated with the Fitch-Margoliash, maximum-parsimony and maximum-likelihood algorithms. Bar, 0.01 substitutions per nucleotide position. 
Chemical), which works as an oxygen absorber and $\mathrm{CO}_{2}$ generator, for up to 14 days at $25^{\circ} \mathrm{C}$. Acid production from sugars was tested at $25{ }^{\circ} \mathrm{C}$ by using phenol red broth base (Becton Dickinson) with a modification that $2 \% \mathrm{NaCl}$ solution was used instead of distilled water. The presence of flexirubin-type pigments was determined by the bathochromatic shift test by using $20 \%(\mathrm{w} / \mathrm{v}) \mathrm{KOH}$ solution (Bernardet et al., 2002; McCammon \& Bowman, 2000). The presence of catalase activity was revealed by the production of oxygen bubbles by the cells when mixed with $3 \%(\mathrm{v} / \mathrm{v}) \mathrm{H}_{2} \mathrm{O}_{2}$ on a glass slide. The presence of oxidase activity was determined by oxidation of a $1 \%(\mathrm{w} / \mathrm{v})$ $N, N, N^{\prime}, N^{\prime}$-tetramethyl-p-phenylenediamine solution. Indole production was determined with Kovacs' indole reagent on SIM agar (Becton Dickinson) supplemented with $2 \% \mathrm{NaCl}$. $\mathrm{H}_{2} \mathrm{~S}$ production was determined on Kligler iron agar (Becton Dickinson) supplemented with $2 \% \mathrm{NaCl}$. Degradation of the following macromolecules was tested by using MA as the basal medium and incubation at $25{ }^{\circ} \mathrm{C}$ for 10 days (all w/v; all Sigma): carboxymethylcellulose (CM-cellulose) (1\%), casein ( $2 \%$ skimmed milk), starch $(0.2 \%)$, Tween $20(1 \%)$ and Tween $80(1 \%)$. Degradation was revealed by formation of clear zones around the colonies either directly or after flooding with adequate staining solutions (Smibert \& Krieg, 1994). Hydrolysis of L-tyrosine (0.5\%, w/v; Sigma) and xylan $(1 \%, \mathrm{w} / \mathrm{v}$; Sigma) was tested by using MA as the basal medium (Barrow \& Feltham, 1993). Hydrolysis of gelatin $(1 \%, \mathrm{w} / \mathrm{v}$; Sigma) and urea (2\%, w/v; Sigma) was determined as described by Lányí (1987) with a modification that $2 \%$ $\mathrm{NaCl}$ solution was used instead of distilled water. DNase activity was determined with DNase test agar (Becton Dickinson) supplemented with $2 \% \mathrm{NaCl}$. Other biochemical tests and enzyme activity tests were performed by using the API 20NE and API ZYM kits (bioMérieux) prepared according to the manufacturer's instructions except that bacterial strains were suspended in distilled water supplemented with $2 \%(\mathrm{w} / \mathrm{v}) \mathrm{NaCl}$. Antibiotic resistance was determined with the disc diffusion method by using commercial antibiotic-impregnated discs (BBL Becton Dickinson). After 7 days of incubation at $25^{\circ} \mathrm{C}$ on MA, the results were interpreted according to the guidelines provided by CLSI (2009).

Cells of strain PSC $33^{\mathrm{T}}$ were strictly aerobic, Gramreaction-negative, motile by gliding and rod-shaped (see Fig. S1 available in IJSEM Online). The detailed results of physiological and biochemical analyses are given in Table 1 and the species description below. As shown in Table 1, several phenotypic characters readily distinguished strain $\mathrm{PSC} 3^{\mathrm{T}}$ from phylogenetically related species. In particular, $N$-acetyl- $\beta$-glucosaminidase activity was found in strain PSC $33^{\mathrm{T}}$ exclusively.

For cellular fatty acid analysis, strain $\operatorname{PSC} 33^{\mathrm{T}}$ and the six reference strains were grown on MA for 3 days at $25{ }^{\circ} \mathrm{C}$ and the methyl esters were analysed by GLC (HP 6890; Hewlett Packard) and the MIDI aerobe method (Sherlock version 4.0) according to the instructions of the Microbial Identification System (MIDI, 1999; TSBA40 database). For
$\mathrm{G}+\mathrm{C}$ content analysis, the DNA of strain $\mathrm{PSC}^{\mathrm{T}}{ }^{\mathrm{T}}$ was prepared in duplicate and analysed by the thermal denaturation method of Marmur \& Doty (1962). Polar lipids were analysed by using standard procedures (Minnikin et al., 1984). Extracted lipids were separated by two-dimensional TLC and identified by spraying with the appropriate detection reagents (Minnikin et al., 1984; Komagata \& Suzuki, 1987). Isoprenoid quinones were extracted from $200 \mathrm{mg}$ freeze-dried cells, purified according to the method of Minnikin et al. (1984) and analysed by HPLC as described by Collins (1994).

The cellular fatty acid profile of strain PSC $33^{\mathrm{T}}$ is described in Table 2. The predominant components were saturated fatty acids iso- $\mathrm{C}_{15: 0}(34.0 \%)$, iso- $\mathrm{C}_{17: 0} 3-\mathrm{OH}(22.3 \%)$, iso- $\mathrm{C}_{15: 1} \mathrm{G}(12.6 \%)$ and $\mathrm{C}_{15: 0} 3-\mathrm{OH}(7.5 \%)$ and monounsaturated fatty acid iso- $\mathrm{C}_{17: 1} \omega 9 c(7.6 \%)$. The fatty acid profile of strain PSC $33^{\mathrm{T}}$ was essentially similar to those of the six reference strains except for the presence of $\mathrm{C}_{15: 0} 3$ $\mathrm{OH}$ and the absence of iso- $\mathrm{C}_{15: 0} 3-\mathrm{OH}$ (Table 2). The only isoprenoid quinone of strain PSC $33^{\mathrm{T}}$ was menaquinone- 6 (MK-6; 100\%); MK-6 is the only or major respiratory quinone in all Aquimarina species and all members of the family Flavobacteriaceae. The polar lipid compositions of strain PSC $33^{\mathrm{T}}$ and A. macrocephali JCM $15542^{\mathrm{T}}$ were very similar, with an unknown amino lipid (AL1) and two unknown polar lipids (L1-L2) as the major components (Fig. 2). Strain PSC $33^{\mathrm{T}}$ differed from A. macrocephali JCM $15542^{\mathrm{T}}$ by a large amount of phosphatidylethanolamine and the presence of two additional unidentified aminolipids (Fig. S2). The DNA G $+\mathrm{C}$ content of strain $P S C 33^{\mathrm{T}}$ was $37.9 \pm 0.3 \mathrm{~mol} \%$ (mean \pm SD of 3 determinations), a value in the range of recognized Aquimarina species (Table 1).

Phylogenetic inference and phenotypic data clearly indicate that strain PSC $33^{\mathrm{T}}$ represents a novel species of the genus Aquimarina, for which the name Aquimarina mytili sp. nov. is proposed. On the basis of new data obtained in this study, an emended description of A. macrocephali is also presented.

\section{Description of Aquimarina mytili sp. nov.}

Aquimarina mytili (my'ti.li. L. n. mytilus $-i$ a kind of mussel, sea mussel, an edible mussel, and also a scientific genus name; L. gen. n. mytili of a sea mussel, Mytilus, reflecting isolation of the type strain from Mytilus coruscus).

Cells are Gram-reaction-negative, strictly aerobic rods, motile by gliding, approximately $0.3-0.4 \mu \mathrm{m}$ in diameter and $1.2-3.0 \mu \mathrm{m}$ in length. Colonies on MA are circular with entire margins, convex, smooth, opaque, orangepigmented and approximately $1.0-2.0 \mathrm{~mm}$ in diameter after 3 days at $25{ }^{\circ} \mathrm{C}(\mathrm{pH} 7)$. Growth occurs on MA, but not on GYEA, NA, R2A agar or TSA. Growth occurs with 1-4\% (w/v) NaCl (optimum, 2\%), at pH 7-9 and at 15$37{ }^{\circ} \mathrm{C}$ (optimum, $25-30{ }^{\circ} \mathrm{C}$ ). Oxidase- and catalase-positive. Flexirubin-type pigments are absent (KOH-test-negative). Nitrate is reduced. Arginine dihydrolase activity is absent. 
Table 1. Differential phenotypic characteristics of strain $\mathrm{PSC}_{3}{ }^{\top}$ and the type strains of recognized Aquimarina species

Strains: 1 , PSC33 ${ }^{\mathrm{T}} ; 2$, A. brevivitae $\mathrm{KCTC} 12390^{\mathrm{T}} ; 3$, A. intermedia JCM $13506^{\mathrm{T}} ; 4$, A. latercula JCM 8515 ${ }^{\mathrm{T}} ; 5$, A. macrocephali JCM $15542^{\mathrm{T}}$; 6 , A. muelleri KCTC $12285^{\mathrm{T}}$; 7, A. spongiae $\mathrm{A}^{\mathrm{T}}$. +, Positive/susceptible; -, negative/resistant. Data are from this study unless indicated otherwise. All strains were positive for hydrolysis of casein, gelatin and starch, activity of oxidase, acid phosphatase, alkaline phosphatase, esterase (C4), leucine arylamidase and naphthol-AS-BI-phosphohydrolase, and susceptibility to amikacin, gentamicin, kanamycin, polymyxin B and streptomycin, but negative for production of indole, acid production from D-fructose, D-galactose, lactose, D-mannitol, L-rhamnose, sucrose and D-xylose, hydrolysis of tyrosine and urea, and activity of cystine arylamidase, $\alpha$-fucosidase, $\alpha$-galactosidase, $\alpha$-glucosidase, $\beta$-glucuronidase, lipase (C14) and $\alpha$ mannosidase.

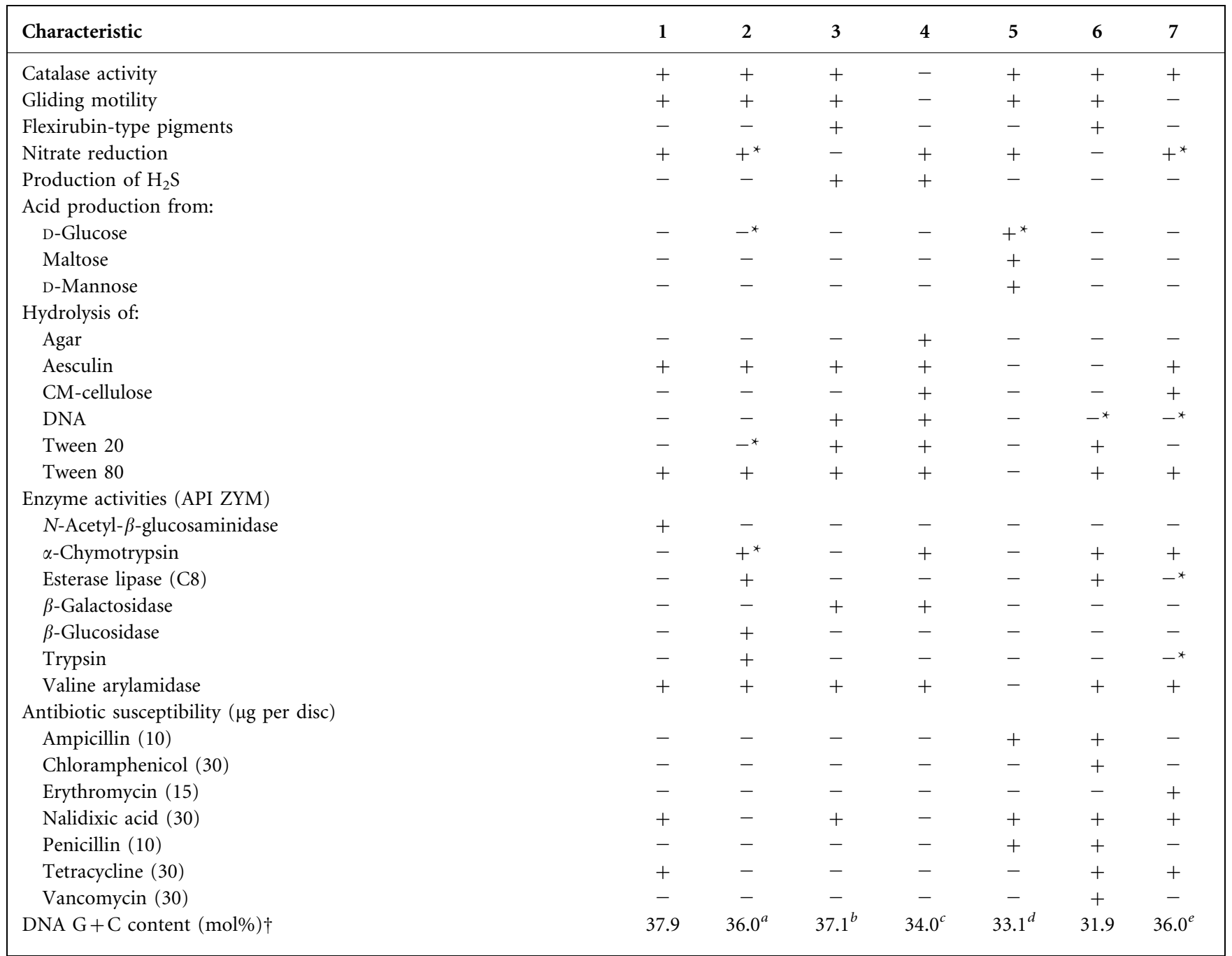

*Opposite results were reported by Yoon et al. (2006), Miyazaki et al. (2010), Nedashkovskaya et al. (2005) and Yoon et al. (2011). $\dagger$ Data from: $a$, Yoon et al. (2006); b, Nedashkovskaya et al. (2006); c, Lewin (1969); d, Miyazaki et al. (2010); e, Yoon et al. (2011).

$\mathrm{H}_{2} \mathrm{~S}$ and indole are not produced. Acid is not produced from D-fructose, D-galactose, D-glucose, lactose, maltose, Dmannitol, D-mannose, L-rhamnose, sucrose or D-xylose. Hydrolyses aesculin, casein, gelatin, starch and Tween 80, but not agar, CM-cellulose, DNA, Tween 20, L-tyrosine, urea or xylan. In API ZYM strips, positive for $N$-acetyl- $\beta$ glucosaminidase, acid phosphatase, alkaline phosphatase, esterase (C4), leucine arylamidase, naphthol-AS-BI-phosphohydrolase and valine arylamidase activities, but negative for $\alpha$-chymotrypsin, cystine arylamidase, esterase lipase
(C8), $\alpha$-fucosidase, $\alpha$-galactosidase, $\beta$-galactosidase, $\alpha$-glucosidase, $\beta$-glucosidase, $\beta$-glucuronidase, lipase (C14), $\alpha$ mannosidase and trypsin activities. Cells are sensitive to ( $\mu \mathrm{g}$ per disc, unless otherwise indicated) amikacin (30), gentamicin (10), kanamycin (30), nalidixic acid (30), polymyxin B (300 IU), streptomycin (10) and tetracycline (30), but resistant to ampicillin (10), chloramphenicol (30), erythromycin (15), penicillin (10 IU) and vancomycin (30). The major fatty acids $\left(>10 \%\right.$ of the total) are iso- $\mathrm{C}_{15: 0}$, iso- $\mathrm{C}_{17: 0} 3-\mathrm{OH}$ and iso- $\mathrm{C}_{15: 1} \mathrm{G}$. The complete fatty acid 
Table 2. Fatty acid compositions (\%) of strain $\mathrm{PSC}^{\mathrm{T}} 3^{\top}$ and the type strains of recognized Aquimarina species

Strains: 1 , $\mathrm{PSC}_{3}{ }^{\mathrm{T}} ; 2$, A. brevivitae KCTC $12390^{\mathrm{T}} ; 3$, A. intermedia JCM $13506^{\mathrm{T}} ; 4$, A. latercula JCM $8515^{\mathrm{T}} ; 5$, A. macrocephali JCM $15542^{\mathrm{T}}$; 6, A. muelleri KCTC $12285^{\mathrm{T}} ; 7$, A. spongiae $\mathrm{A}^{\mathrm{T}}$. All data are from this study. All strains studied were grown on MA at $25{ }^{\circ} \mathrm{C}$ for 3 days. Tr, Trace $(<1 \%) ;-$, not detected. Fatty acids amounting to $<1 \%$ of the total in all strains are not shown.

\begin{tabular}{|c|c|c|c|c|c|c|c|}
\hline Fatty acid & 1 & 2 & 3 & 4 & 5 & 6 & 7 \\
\hline $\mathrm{C}_{14: 0}$ & $\operatorname{Tr}$ & $\operatorname{Tr}$ & $\operatorname{Tr}$ & $\operatorname{Tr}$ & 2.8 & 1.4 & - \\
\hline $\mathrm{C}_{15: 0}$ & 2.0 & 3.8 & 1.9 & 4.8 & 1.7 & - & 2.4 \\
\hline$C_{16: 0}$ & 3.3 & 1.0 & 4.4 & 5.5 & 3.9 & 10.2 & 1.9 \\
\hline $\mathrm{C}_{18: 0}$ & 1.7 & $\operatorname{Tr}$ & 3.3 & 3.9 & - & 6.7 & 1.0 \\
\hline $\mathrm{C}_{17: 1} \omega 6 c$ & - & - & $\operatorname{Tr}$ & 1.2 & - & - & - \\
\hline iso- $\mathrm{C}_{13: 0}$ & $\operatorname{Tr}$ & $\operatorname{Tr}$ & $\operatorname{Tr}$ & $\operatorname{Tr}$ & 4.4 & 1.9 & $\operatorname{Tr}$ \\
\hline iso- $\mathrm{C}_{15: 0}$ & 34.0 & 21.5 & 27.1 & 19.2 & 16.8 & 21.1 & 38.1 \\
\hline iso- $\mathrm{C}_{16: 0}$ & 1.4 & 2.5 & 1.6 & 4.2 & $\operatorname{Tr}$ & - & 1.3 \\
\hline iso- $\mathrm{C}_{15: 1} \mathrm{G}$ & 12.6 & 12.3 & 12.5 & 11.0 & 8.7 & 6.1 & 15.5 \\
\hline iso- $\mathrm{C}_{16: 1} \mathrm{H}$ & - & 1.6 & 1.2 & - & - & - & - \\
\hline iso- $\mathrm{C}_{16: 1} \mathrm{G}$ & - & - & - & 1.6 & - & - & 1.2 \\
\hline iso- $\mathrm{C}_{17: 1} \omega 9 c$ & 7.6 & 5.59 & 9.2 & 5.6 & 6.0 & 9.4 & 8.2 \\
\hline anteiso- $\mathrm{C}_{15: 0}$ & 1.0 & $\operatorname{Tr}$ & $\operatorname{Tr}$ & $\operatorname{Tr}$ & - & - & $\operatorname{Tr}$ \\
\hline $\mathrm{C}_{15: 0} 3-\mathrm{OH}$ & 7.5 & $\operatorname{Tr}$ & - & - & - & - & $\operatorname{Tr}$ \\
\hline $\mathrm{C}_{16: 0} 3-\mathrm{OH}$ & $\operatorname{Tr}$ & 1.5 & $\operatorname{Tr}$ & 2.0 & 14.5 & 1.5 & 0.7 \\
\hline iso- $\mathrm{C}_{15: 0} 3-\mathrm{OH}$ & - & 4.9 & 4.5 & 4.1 & 4.8 & 4.7 & 5.3 \\
\hline iso- $\mathrm{C}_{16: 0} 3-\mathrm{OH}$ & - & 2.4 & 1.1 & 1.0 & - & - & $\operatorname{Tr}$ \\
\hline iso- $\mathrm{C}_{17: 0} 3-\mathrm{OH}$ & 22.3 & 30.4 & 23.3 & 23.5 & 24.4 & 28.8 & 18.1 \\
\hline Summed feature $3^{*}$ & 3.9 & 4.8 & 3.5 & 4.2 & 8.9 & 8.2 & 3.4 \\
\hline $\begin{array}{l}\text { Unknown ECL } \\
16.582 \dagger\end{array}$ & $\operatorname{Tr}$ & 1.8 & $\operatorname{Tr}$ & $\operatorname{Tr}$ & - & - & - \\
\hline
\end{tabular}

${ }^{*}$ Summed feature 3 comprises $\mathrm{C}_{16: 1} \omega 7 c$ and/or iso- $\mathrm{C}_{15: 0}$ 2-OH. $\dagger \mathrm{ECL}$, Equivalent chain-length.

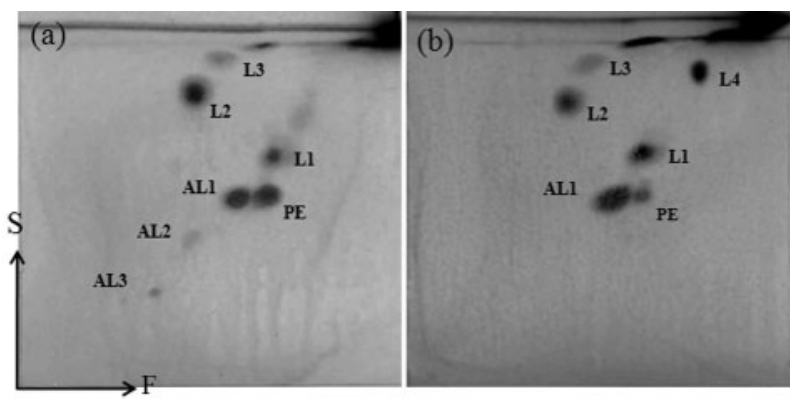

Fig. 2. Two-dimensional TLC pattern of the total polar lipids from strain PSC33 ${ }^{\top}$ (a) and Aquimarina macrocephali JCM $15542^{\top}$ (b). $\mathrm{PE}$, Phosphatidylethanolamine; L1-L4, unidentified polar lipids; AL1-3, unidentified aminolipids. The solvent systems used were chloroform/methanol/water $(65: 25: 3.8$, by vol.) for the first dimension ( $F$ ) and chloroform/methanol/acetic acid/water ( $40: 7.5: 6: 1.8$, by vol.) for the second dimension (S). Phosphomolybdic acid (Sigma) was used to detect all lipids. composition is given in Table 2 . The only isoprenoid quinone is MK-6. The major polar lipids are phosphatidylethanolamine, an unknown aminolipid and two unknown polar lipids.

The type strain, PSC $33^{\mathrm{T}}\left(=\right.$ KCTC $\left.23302^{\mathrm{T}}=\mathrm{JCM} 17454^{\mathrm{T}}\right)$, was isolated from a mussel, Mytilus coruscus, collected from the South Sea, Republic of Korea. The DNA G + C content of the type strain is $37.9 \mathrm{~mol} \%$.

\section{Emended description of Aquimarina macrocephali Miyazaki et al. 2010}

The description is as given by Miyazaki et al. (2010) with the following addition. Polar lipids are phosphatidylethanolamine, an unknown aminolipid and four unknown polar lipids.

\section{Acknowledgements}

This research was supported by the 21C Frontier Microbial Genomics and Applications Center Program of the Ministry of Education, Science \& Technology and the project on survey and excavation of Korean indigenous species of the National Institute of Biological Resources (NIBR) under the Ministry of Environment, Republic of Korea. We thank Dr D.-C. Oh for kindly providing the type strain of A. spongiae.

\section{References}

Barrow, G. I. \& Feltham, R. K. A. (editors) (1993). Cowan and Steel's Manual for the Identification of Medical Bacteria, 3rd edn. Cambridge: Cambridge University Press.

Bernardet, J. F., Nakagawa, Y., Holmes, B. \& Subcommittee on the taxonomy of Flavobacterium and Cytophaga-like bacteria of the International Committee on Systematics of Prokaryotes (2002). Proposed minimal standards for describing new taxa of the family Flavobacteriaceae and emended description of the family. Int J Syst Evol Microbiol 52, 1049-1070.

Chun, J. \& Goodfellow, M. (1995). A phylogenetic analysis of the genus Nocardia with $16 \mathrm{~S}$ rRNA gene sequences. Int J Syst Bacteriol 45, 240-245.

Chun, J., Lee, J.-H., Jung, Y., Kim, M., Kim, S., Kim, B. K. \& Lim, Y. W. (2007). EzTaxon: a web-based tool for the identification of prokaryotes based on $16 \mathrm{~S}$ ribosomal RNA gene sequences. Int J Syst Evol Microbiol 57, 2259-2261.

CLSI (2009). Performance standards for antimicrobial susceptibility testing; 19th Informational Supplement, CLSI document M100-S19 (ISBN 156238-690-5). Wayne, PA: Clinical and Laboratory Standards Institute.

Collins, M. D. (1994). Isoprenoid quinones. In Chemical Methods in Prokaryotic Systematics, pp. 265-309. Edited by M. Goodfellow \& A. G. O'Donnell. Chichester: Wiley.

Felsenstein, J. (1985). Confidence limits on phylogenies: an approach using the bootstrap. Evolution 39, 783-791.

Felsenstein, J. (1993). PHYLIP (phylogeny inference package), version 3.5c. Distributed by the author. Department of Genome Sciences, University of Washington, Seattle, USA.

Fitch, W. M. (1971). Toward defining the course of evolution: minimum change for a specific tree topology. Syst Zool 20, 406416. 
Fitch, W. M. \& Margoliash, E. (1967). Construction of phylogenetic trees. Science 155, 279-284.

Jukes, T. H. \& Cantor, C. R. (1969). Evolution of protein molecules. In Mammalian Protein Metabolism, vol. 3, pp. 21-132. Edited by H. N. Munro. New York: Academic Press.

Komagata, K. \& Suzuki, K. (1987). Lipid and cell-wall analysis in bacterial systematics. Methods Microbiol 19, 161-207.

Lányí, B. (1987). Classical and rapid identification methods for medically important bacteria. Methods Microbiol 19, 1-67.

Lewin, R. A. (1969). A classification of flexibacteria. J Gen Microbiol 58, 189-206.

Marmur, J. \& Doty, P. (1962). Determination of the base composition of deoxyribonucleic acid from its thermal denaturation temperature. J Mol Biol 5, 109-118.

McCammon, S. A. \& Bowman, J. P. (2000). Taxonomy of Antarctic Flavobacterium species: description of Flavobacterium gillisiae sp. nov., Flavobacterium tegetincola sp. nov., and Flavobacterium xanthum sp. nov., nom. rev. and reclassification of [Flavobacterium] salegens as Salegentibacter salegens gen. nov., comb. nov. Int J Syst Evol Microbiol 50, 1055-1063.

MIDI (1999). Sherlock Microbial Identification System Operating Manual, version 3.0. Newark, DE: MIDI, Inc.

Minnikin, D. E., O'Donnell, A. G., Goodfellow, M., Alderson, G., Athalye, M., Schaal, A. \& Parlett, J. H. (1984). An integrated procedure for the extraction of bacterial isoprenoid quinones and polar lipids. J Microbiol Methods 2, 233-241.

Miyazaki, M., Nagano, Y., Fujiwara, Y., Hatada, Y. \& Nogi, Y. (2010). Aquimarina macrocephali sp. nov., isolated from sediment adjacent to sperm whale carcasses. Int J Syst Evol Microbiol 60, 2298-2302.

Nedashkovskaya, O. I., Kim, S. B., Lysenko, A. M., Frolova, G. M., Mikhailov, V. V., Lee, K. H. \& Bae, K. S. (2005). Description of Aquimarina muelleri gen. nov., sp. nov., and proposal of the reclassification of [Cytophaga] latercula Lewin 1969 as Stanierella latercula gen. nov., comb. nov. Int J Syst Evol Microbiol 55, 225-229.

Nedashkovskaya, O. I., Vancanneyt, M., Christiaens, L., Kalinovskaya, N. I., Mikhailov, V. V. \& Swings, J. (2006). Aquimarina intermedia sp. nov., reclassification of Stanierella latercula (Lewin 1969) as Aquimarina latercula comb. nov. and Gaetbulimicrobium brevivitae Yoon et al. 2006 as Aquimarina brevivitae comb. nov. and emended description of the genus Aquimarina. Int J Syst Evol Microbiol 56, 20372041.
Saitou, N. \& Nei, M. (1987). The neighbor-joining method: a new method for reconstructing phylogenetic trees. Mol Biol Evol 4, 406425.

Smibert, R. M. \& Krieg, N. R. (1994). General characterization. In Methods for General and Molecular Bacteriology, pp. 607-654. Edited by P. Gerhardt, R. G. E. Murray, W. A. Wood \& N. R. Krieg. Washington, DC: American Society for Microbiology.

Swofford, D. L. (1998). Phylogenetic analysis using parsimony (PAUP), version 4. Sunderland, MA: Sinauer Associates.

Thompson, J. D., Gibson, T. J., Plewniak, F., Jeanmougin, F. \& Higgins, D. G. (1997). The CLUSTAL_X windows interface: flexible strategies for multiple sequence alignment aided by quality analysis tools. Nucleic Acids Res 25, 4876-4882.

Tindall, B. J., Rosselló-Móra, R., Busse, H. J., Ludwig, W. \& Kämpfer, P. (2010). Notes on the characterization of prokaryote strains for taxonomic purposes. Int J Syst Evol Microbiol 60, 249-266.

Wayne, L. G., Brenner, D. J., Colwell, R. R., Grimont, P. A. D., Kandler, O., Krichevsky, M. I., Moore, L. H., Moore, W. E. C., Murray, R. G. E. \& other authors (1987). International Committee on Systematic Bacteriology. Report of the ad hoc committee on reconciliation of approaches to bacterial systematics. Int J Syst Bacteriol 37, 463-464.

Yang, S.-J. \& Cho, J.-C. (2008). Gaetbulibacter marinus sp. nov., isolated from coastal seawater, and emended description of the genus Gaetbulibacter. Int J Syst Evol Microbiol 58, 315-318.

Yang, S.-H., Kwon, K. K., Lee, H.-S. \& Kim, S.-J. (2006). Shewanella spongiae sp. nov., isolated from a marine sponge. Int J Syst Evol Microbiol 56, 2879-2882.

Yi, H. \& Chun, J. (2011). Aquimarina addita sp. nov., isolated from seawater. Int J Syst Evol Microbiol 61, 2445-2449.

Yoon, J. H., Kang, S. J., Jung, S. Y., Oh, H. W. \& Oh, T. K. (2006). Gaetbulimicrobium brevivitae gen. nov., sp. nov., a novel member of the family Flavobacteriaceae isolated from a tidal flat of the Yellow Sea in Korea. Int J Syst Evol Microbiol 56, 115-119.

Yoon, B. J., You, H. S., Lee, D. H. \& Oh, D. C. (2011). Aquimarina spongiae sp. nov., isolated from marine sponge Halichondria oshoro. Int J Syst Evol Microbiol 61, 417-421.

Yumoto, I., Hirota, K., Yamaga, S., Nodasaka, Y., Kawasaki, T., Matsuyama, H. \& Nakajima, K. (2004). Bacillus asahii sp. nov., a novel bacterium isolated from soil with the ability to deodorize the bad smell generated from short-chain fatty acids. Int J Syst Evol Microbiol 54, 1997-2001. 